\title{
Is Personal Life Purpose Replacing Shared Worldview as Youths Increasingly Individuate? Implications for Educators
}

\author{
Seana Moran ${ }^{1}$ \\ Clark University \\ Worcester, MA, USA
}

\begin{abstract}
This conceptual paper integrates scholarship from psychology, sociology, education, and philosophy to pose and consider important questions regarding how life purpose and worldview relate, especially in turbulent socio-cultural times. This exploration can help educators consider life purpose not as an individual attribute but rather as a practice. Both worldview and life purpose can be given from a culture or can be chosen by the individual, with more cultures increasingly incorporating individualized choice. However, it is important that individualization not become solely self-focused. Individuals' purposes interact to weave a participatory worldview of personal contributions to the common good: "threaded" life purposes compose the social fabric of shared worldviews such that worldview and life purpose reciprocally compose each other to maintain self-regulation despite turbulence or transitions in social institutions. On this view, educators are challenged to design practice opportunities for students to strengthen the prosocial interdependence of their life purposes within the community, by acting in situations in which others are influenced by-and provide feedback on-the student's purpose-pursuing actions. Ideally, students interact with people who have different purposes so everyone can master interweaving diversity to strengthen society. Thereby, educators support skills to value prosocial interdependence.
\end{abstract}

Keywords: life purpose; youth; worldview; individualization; prosocial, college.

\section{Introduction}

Both worldview and life purpose influence sense of life coherence and understandings of how self and context interact. But there has been little focus directly addressing how they relate to each other. A worldview is an implicit theory (Dweck, 1996) that explains what exists in the world, how we can know, and why these understandings of "how the world works" matter (Koltko-Rivera,

${ }^{1}$ Corresponding author: Seana Moran, smoran@clarku.edu 
2004; Reason, 1998). Researchers examine how worldviews defend psyches against existential threats (e.g., McGregor, 2006; Proulx, 2009). A life purpose is a schema of one's future self that proposes why a person exists, what contribution the person aims to make, and how that contribution matters to society (Moran, 2009). Researchers investigate life purpose as a mental tool providing psychological benefits (e.g., Bronk, 2014). Life purpose development in adolescence and young adulthood has become a focus in the early $21^{\text {th }}$ century not only in psychological and educational research but also in general-interest books (e.g., Burnett, \& Evans, 2016; Damon, 2008).

This paper frames relational issues between worldview and life purpose that may affect educators' support of positive youth development. After a brief overview of the conceptual overlaps between worldview and life purpose, this paper considers four questions:

1. Why now has life purpose become a focus for youth development and education?

2. In individualistic Western societies, with the United States being the most extremely individualistic based on Hofstede's (2001) model (Moran, $2017 \mathrm{~b}$ ), is personal life purpose replacing culturally based, shared worldviews as a psychological organizer of experience and behavior?

3. Is the proliferation of the life purpose concept worldwide an indication of a broader contagion of individualization, as researchers in various traditionally collectivistic countries note the long-term goals of their youth shifting toward self-oriented rather than community benefits (Moran, 2017a)?

4. How does shifting from a given worldview and life purpose to a chosen worldview and/or life purpose change what youths must learn to become prosocial contributors to society?

In short, this paper proposes that worldviews and life purposes both create meaning and draw meaning from each other. Around the world, youths are increasingly required to consciously choose a life purpose rather than depend solely on an inherited and often tacit worldview. Individualization is spreading across cultures, which could lead toward two extremes: (a) growth in selfinterested purposes competing to consume shared resources, or (b) diversification of purposes prosocially interacting to weave a stronger social fabric. Teaching the concept of life purpose cognitively seems insufficient to help youths construct their own life purposes to guide their behavior. Learning to pursue a purpose requires emotional education through lived experiences, which can integrate into personal meaning one's efforts to help others. Realworld opportunities for youths to gain feedback directly from beneficiaries of their prosocial efforts are more likely than decontextualized and abstractly graded school assignments to develop effective purposes. Why? Because the experience and the feedback demonstrate how youths' pursuits matter to other individuals' well-being. Furthermore, opportunities for youths with diverse worldviews and purposes to interact can demonstrate how youths' pursuits matter to societal well-being. Complementarities among tacit worldviews and espoused life purposes reorient education away from youths consuming school 
offerings toward developing in youths a "vocation" mentality to do good for and with others.

Therefore, this paper is simultaneously (a) an exploration of contemporary shifts in meaning-making from shared worldviews to personal life purposes, and the growing interest in more individualistic conceptions of youth life purpose (Hill, Burrow \& Sumner, 2013); and (b) a warning about educational challenges ahead because, in turbulent times when different and sometimes conflicting worldviews interact (Note, Fornet-Betancout, Estermann, \& Aerts, 2009), it is critical that life purposes incorporate "how I matter" to society and not only "what I gain" from society (Sullivan, 2016). Otherwise, the social fabric may tear as too many individuals consume shared resources without doing their part to replenish or strengthen them. One college student aimed to address this warning: "I think my life purpose is to try to leave the world a better place...There are so many issues around the world.... A lot of the time, the only way to get out of a bad situation is for someone to lend a helping hand." ${ }^{2}$

\section{Function of Worldview and Life Purpose: Meaning-Making}

Both worldview and life purpose make meaning (Polanyi, \& Prosch, 1975; Stillman \& Baumeister, 2009). Meaning interprets new experiences and information based on what a person already understands (Bruner, 1990). Without meaning, the world would seem absurd (Proulx, 2009). When a situation lacks meaning, people feel uncertain (McGregor, Prentice, \& Nash, 2009). Individuals' self-concepts and self-esteem can be strongly affected by uncertain situations they cannot understand (Van den Bos, 2009). Extremely incomprehensible situations might even trigger a psychologically painful existential crisis (Proulx, 2009). Thinking about existential issues is resource intensive for the human brain (Moran, 2013). So individuals generally fall back on existing explanatory frameworks-like worldviews and life purposes-to help them cope (Van den Bos, 2009).

Individuals try to link perceptions into meaningful stories of their lives (Bruner, 1986). If an individual can only know their own experiences, then only personal meaning is possible (personal communication, anonymous reviewer). However, humans share their life stories with others in everyday interactions (Bamberg \& Georgakopoulou, 2008), which allows for social meanings to emerge (personal communication, anonymous reviewer). According to Vygotsky's socio-cultural framework (see Moran \& John-Steiner, 2003), individuals' stories interweave into a shared understanding of how the world works. A worldview is born.

The role of the worldview is to provide explanations that make the world appear under control. Children absorb their community's worldview through religion, family, and other social institutions. If the everyday learning processes of assimilation and accommodation are insufficient for understanding an uncertain situation, a worldview provides a ready-made psychological defense (Van den Bos, 2009). Since worldviews are shared, people who believe the same

\footnotetext{
${ }^{2}$ Quotes of youths' perspectives of their worldviews and life purposes are interspersed in this paper to exemplify key points in the argument. They were collected by the author in the northeast United States as part of a large study.
} 
worldview feel safer by corroborating each other's stories of how the world works. Implicit social pressure to maintain the worldview leads most idiosyncratic explanations to eventually be rejected or absorbed into the agreedupon worldview (McGregor et al., 2009).

But in adolescence, as self-awareness and abstract thinking strengthen, youths may feel a shared worldview is insufficient for a particular uncertain situation. Some youths may interpret this uncertainty positively as an opportunity (Moran, 2017b) for them to pursue a "zealous ideal" (McGregor, 2006). A life purpose might start as a shift in understanding how the world could work, i.e., become a personal worldview (McGregor et al., 2009; Stillman \& Baumeister, 2009). Then this ideal blossoms into an intentional path for the youth to bring that possibility into reality (Moran, 2010). Life purpose is more agentic than worldview. It feels less defensive against an existential threat and more proactive toward an existential possibility.

Life purpose is usually at least partly idiosyncratic because it adds the person's subjective perspective of "my contribution" to the world (Moran, 2017b; Pizzolato, 2003). For example, one youth considered her purpose: "Healing and empowering women of color. As a woman of color I am aware that there needs to be a lot of healing work to be done. We carry a lot of weight on our shoulders and it is time that we lift these burdens off and speak." Life purpose offers a compass to institutionalize one's life course (Kohli, 2007) through a long-term intention to act integrating both personal meaning and expected prosocial influence (Damon, 2008), which over one's life span, can expand in the number and strength of life domains it influences (McKnight, \& Kashdan, 2009). For example:

"I think my life's purpose is to help people. Especially the underrepresented people in the world....through medicine and health....I have very close family members dying in Africa, and I know that there are smart people in Africa and places in Africa with vibrant life where health is a problem because of very few resources and very little education, but that can change."

Life purpose and worldview are often associated through religion. Religious worldviews, because of their multiple dimensions of meaning (Emmons, 2005; Van Tongeren, McIntosh, Raad, \& Pae, 2013), can be particularly helpful for alleviating uncertainty (Cranney, 2013; Van den Bos, 2009) by providing a Godgiven integration of values, behaviors, and morals for youth to follow (Moran, 2014). Religion sometimes is considered a cornerstone of purpose (e.g., "vocation," Clydesdale, 2016), and some youths show religious life purposes (e.g., Emmons, 2005; Tirri, \& Quinn, 2010): “I found that living my life listening to God and thinking of others was more fulfilling than a concern for myself." But religion is not necessary for purpose (Vidal, 2008), as another youth conveyed: "As a non-religious individual, I do not feel that life has any meaning/purpose except for that which we define ourselves. I can however make those who do believe they serve a purpose feel good by helping them achieve their goals." 


\section{Why Now? Turbulent Times}

Shared worldviews feel less reliable these days (Dent, 1999). The social institutions that people have depended on to give meaning to life experiences are perceived to be shifting rapidly, creating a downward spiral of uncertainty and absurdity. The religious worldview of a God-in-charge "is dead," according to Nietzsche and contemporary atheists. The scientific worldview of a dependable "clockwork" mechanism is not as timely (Reason, 1998). With the influence of traditional family or religious worldviews waning (e.g., Pew Research Center, 2014), and no new clear frameworks to help youths understand what's going on in the world, some youths have started to reduce direct social contact, interpersonal relationships, and institutions as too complex to engage (Smith, Christoffersen, Davison, \& Herzog, 2011; Turkle, 2011) and instead prefer mediated communications that streamline messaging and project cultivated selfimages (Turkle, 2011).

Through these digital media that globalize messaging, youths now encounter various, changing, and sometimes competing worldviews with such acceleration that it is almost more than the human mind can process (Clydesdale, 2016; Sullivan, 2016). Youth feel isolated from others (Beck, \& Beck-Gernsheim, 2002). Long-standing social categories like gender, ethnicity, and identity are reconfiguring from categorical into spectral or multidimensional concepts. As this reconfiguration occurs, individuals are confused about how to behave and interact with each other-social norms are in transition. What used to be givens are becoming choices.

The proliferation of choices can feel overwhelming. It takes time and effort to consider the options and decide what is right for oneself. More youth today delay taking on adult responsibility and rather extend an "exploratory" life stage called "emerging adulthood" (Schwartz, Côté, \& Arnett, 2005). Instead of perpetuating traditions of marriage, family, secure work and financial independence (US Census Bureau, 2014), American youths face ever-changing "lifestyle choices." They continuously delay acceptance of responsibilities, even though research shows that commitment to meaningful pursuits would be more useful (Bronk, 2014; Schwartz et al., 2005). There is no longer the expectation - or for some, even a hope - that life will work out as well for them as it did for their parents (Atkinson, 2007; Schwartz et al., 2005; Smith et al., 2011).

Youths feel trapped by too much choice. In the United States, one in five 20somethings are lost in perpetual identity confusion (Côté, 2016). Perhaps most disconcerting, youths don't seem to recognize the moral implications of their choices - they are solipsistic and inconsiderate of their effect on others (Honneth, 2004). Although across adolescence most youths eventually gravitate toward some type of life aim, overall the largest group - two in five youth - show little purpose development (Malin, Reilly, Quinn, \& Moran, 2014; Moran, 2009). Only one in four youth age 11-26 express a life purpose that considers impact on others (Moran, 2009). The same proportion expresses goals that benefit only themselves: for example, one college student claimed: "Life is chaotic and meaningless, so I choose to spend it ...enjoying my own worldly pursuits. Why? I might as well. There is no life purpose. Absurdism is the natural consequence of thought. Plan? I'll just have to wait and see." 


\section{Is Life Purpose Replacing Worldview?}

Even though many youths may not yet be succeeding in purpose development, are personal life purposes replacing shared worldviews as a psychological organizer of subjective experience? Since traditional worldviews often include beliefs that they are the "only correct beliefs" (Koltko-Rivera, 2004), encounters with other worldviews in today's globalized society can create confusion and conflict (Note et al., 2009). When youths face options among worldviews (Beck, \& Beck-Gernsheim, 2002), they may feel a loss of meaning (Van Tongeren et al., 2013) as they are left on their own to choose. Although some may become curious and integrate elements of various worldviews (Proulx, 2009), others may simply fall back to defending their own worldview (McGregor et al., 2009; Wicklund, 1997). For example, one college student demonstrated this sense of a rudderless future:

"Any purpose or meaning that my life could have is merely a figment of my imagination. I plan to spend my time playing music and engaging in any other activities which make me feel as though I'm having more fun. I can potentially reach a large amount of people through music. Thus, I would be able to influence social change. I would like to eventually influence the end of the war on drugs, capitalism, and the current political system....Plans are foolish. Improvisation is the only possibility here."

In an individualized world (Beck \& Beck-Gernsheim, 2002), life purpose can transform the tacit "reality" of shared worldviews (Koltko-Rivera, 2004; Reason, 1998) into personal worldviews by cobbling together values and goals from disparate sources (Van der Kooij, De Ruyter, \& Miedema, 2015). Eventually, a personal "compass" may define meaning not only in their lives but also of their lives (Schwartz et al., 2005), as one student expressed:

"So many people can achieve great things and make a good life for themselves, they just need a step up and I would like to be able to help with that. I was lucky enough to have been raised in a good environment with many opportunities and I want to be able to give that to others."

But this transition from worldview to purpose takes time. Life purpose develops asynchronously as meaning, intention, and prosocial orientation proceed at different rates (Malin et al., 2014). For example, first-year college students tend to start with worldviews proposing "right answers" from authorities, which become more nuanced and personally defined as students encounter "provocative moments" that their past worldviews can't address (Pizzolato, 2003; Pizzolato, 2005). Furthermore, youths realize they are protagonists of their own meaning-making and start to "repurpose" how past "tried and true" practices apply to their lives (Pizzolato \& Olson, 2016). Life purpose makes youths' future self and lifespan horizon central to their meaning-making (Côté, 2016; Moran, 2017b). But individuals must recognize the social interconnectedness of their life purposes, as one college student mused:

"If people can come out of their trenches and see other perspectives/narratives, and change the method of their thinking, 
we as a society will be able to do amazing things....If we can change the way society thinks, and have everyone see themselves as humans first and "nationality" second, we will be much better off..."

A vague sense of purpose is insufficient (Moran, Bundick, Malin, \& Reilly, 2013). The purpose's aim matters - i.e., what youths anticipate their contribution to be (Damon, 2008). Otherwise, youths drift or dabble in momentary pleasures (Honneth, 2004). Furthermore, the aim must clearly connect personal meaning and beyond-the-self impact so that, as Aristotle (2000) prescribed, youth come to desire the right things for the good life. For example, a young woman described: "I think my life's purpose is to appreciate every day for what it is and to spread as much love and kindness as possible....I know life is short and I want to live a life with a clear conscience knowing I did what I could to improve my life and that of the ones around me with no regrets."

Life purpose should not be considered an individual attribute or private good, but rather a public good that benefits the community (Sullivan, 2016) - not aiming to benefit oneself through consumption or status, but to benefit others through prosocial pursuits (Clydesdale, 2016; Côté, 2016; Moran, 2009). Increasingly, researchers use "purpose" for prosocial life aims and "life goal" for self-benefiting long-term pursuits (e.g., Moran, 2009). Youth themselves increasingly describe the prosocial effects of their efforts in their life purpose:

"My life purpose is to help others as much as possible. Not only the ones in need but everyone you encounter during your life....I come from a third world country and I see every day the hardships people go through.... I hope to work in an NGO that helps the development of third world countries."

Whether life purpose is necessarily prosocial remains in dispute (Moran et al., 2013). Several scholars suggest life purpose advances only the individual's wellbeing (Hill, Burrow, \& Sumner, 2013) or even contraindicates prosociality (Waddington, 2010). Recent studies do not corroborate these arguments. Although life purpose is positively associated with various indicators of wellbeing for the individual (Bronk, 2014), solely self-benefiting pursuits are not (Hill, Burrow, Brandenberger, Lapsley \& Quaranto, 2010; Kasser \& Ryan, 1993). Whereas prosocial purposes energize the significance of the person within community, self-oriented life goals supercede consideration for others (Smith et al., 2011) and relate to loneliness and social rejection. Self-oriented life goals are related to reduced meaning-making (Stillman, \& Baumeister, 2009).

Prosocial interdependence of various individuals' life purposes can provide benefits at the community level as well. Rather than shared worldviews being given to youth "top down" from an authority to stabilize social interactions (Vidal, 2008), life purposes may collaboratively compose a participative worldview "bottom up" through the interweaving of individuals' contributions into the social fabric (Reason, 1998). For example, a youth offered: "I believe I was created to help people in need and be a strong supporter of people less fortunate... I am studying abroad in Chile and it is a fairly poor area and I hope I can communicate within the community and become a person who young people and people in general can look up to and feel happy about." 


\section{Is Life Purpose a Contagion of Individuation?}

Research on life purpose has proliferated to all inhabited continents. Is individualistic life purpose overtaking the world a sign of progress or a setback? An implicit hope of more youths developing life purposes is that, especially if social institutions are in transition, individuals become freed from externally imposed worldviews to become more intentional, responsible contributors to their communities. Yet life purpose may also present a sobering loss: the disintegration of personal and social meaning within a person and of solidarity within communities (Durkheim, 1951; Yan, 2010). Individuals' personal worldviews or life aims may differ enough that difficulties arise in shared sensesof-self, reducing acceptance of who " $\mathrm{I}$ " am in relation to others (personal communication, anonymous reviewer).

Contemporary youth life purpose and personal worldview concepts proliferated first in strongly individualistic societies like Finland (Tirri \& Ubani, 2005) and the United States (see Damon, 2008). Two special issues focused on youth purpose around the world (Moran, 2017a; Moran, 2018b) suggest not all collectivistic cultures lament a shift toward individualistic pursuits - e.g., South Africa (Mason, 2017) and Israel (Heng, Blau, Fulmer, Bi, \& Pereira, 2017). But many showed signs of change.

For example, a Brazilian analysis showed that the reasons youths pursued the same life purpose aim - e.g., work - could vary considerably from communally supporting family to selfishly increasing consumerism (Arantes, Araujo, Pinheiro, Marimon, \& Sastre, 2017). In Mongolia, although most youths still tend to endorse community-minded intrinsic aspirations, some young men endorse self-enhancement, pleasure and power aspirations (Bespalov, Prudnikova, Nyamdorj, \& Vlasov, 2017). Given Singapore's strong societal orientation toward achievement goals, researchers were surprised to find that almost one in five youth reported no clear purpose (Heng et al., 2017).

Thailand's government expressly dictates harmonious social relations, and the Thai language includes specific words that address prosocial mindsets (Balthip, McSherry, Petchruschatachart, Piriyakoontorn, \& Liamputtong, 2017). So it is not surprising that most Thai youth still pursue traditional, community-minded aims. But the Internet and urbanization, coupled with more nuclear families, mean youth have fewer role models for the Thai culture's valued "generous mindset."

Japanese youths now are expected to formulate Western-style identities during college even though traditional Japanese culture and language reinforce the communal and social meanings of emotional identification in relation to others (Kawai \& Moran, 2017). Although Western purposes are built upon personally significant endeavors, Japanese purposes derive from meaning-making with others. So some youths face difficulties meaningfully connecting their current engagements to their future life aims.

Formal curricula for life purpose development exist in Iran (Hedayati, Kuusisto, Gholami, \& Tirri, 2017) and China (Jiang \& Gao, 2018), based on Islamic religion and Communist ideology, respectively. These curricula explicitly specify prosocial aims. Yet, Iranian students endorsed self-oriented, materialistic goals most highly. Similarly, Chinese student teachers tended to feel more negative 
self-transcendent emotions like boredom and disgust, rather than the expected positive emotions of gratitude and optimism, when serving others.

Furthermore, several scholars noted that, with their cultures in flux, more youth were focused on life aims focused on changing their culture (Moran, 2010). This change orientation could be viewed as a setback if it involves individuals grabbing more self-interested power (e.g., Mongolia) or abdicating familial responsibilities (e.g., Shin, Hwang, Cho, \& McCarthy-Donovan, 2013). Or this change orientation could be viewed as progress if it alleviates oppression (e.g., Folgueiras \& Palou, 2018; Hedayati et al., 2017). Although change often creates turbulence in worldviews, change purposes can have prosocial effects. Creative purposes can transform worldviews to be more open and inclusive (Moran, 2010). If enough youths select a non-normative life purpose, they may eventually change their culture generationally by shifting the norm.

This prosocial change orientation was particularly the case in Spain, where youth in both Castilian-cultured Madrid and Catalan-cultured Barcelona faced considerable political and economic challenges. A study in Barcelona addressed college students' considerations of the national unemployment crisis and whether a new model of society should be endorsed (Folgueiras \& Palou, 2018). Students who aimed to change society scored higher on prosocial life goals than those who wanted to conserve the current way of life. But these changesupporting students were more likely to have higher self-oriented life goal scores as well, suggesting that they viewed changing society as benefiting the self also. Students in Madrid are increasingly encouraged to engage in community service to support their prosocial aspirations. Youths who believed their service helped others a lot and whose purposes were strengthened during service work maintained positive feelings toward prosocial efforts, whereas those whose purposes did not change felt fewer positive emotions (Opazo, Aramburuzabala, \& Ramirez, 2018). Yet even with this strongly prosocial result, these students still associated their future purpose-related plans with selfinterest rather than with prosocial impact.

\section{How Can We Educate for Chosen Life Purposes?}

Turbulence in social institutions and increasing worldview options make youths personally responsible to figure out how to live their lives. Can education help? Traditionally charged with preparing youth to deploy relatively standardized skills for careers and citizenship (Van de Werfhorst, 2014), educational institutions now may need to support students" abilities to "thread" their own life purpose with others' purposes. This challenge adds to the current debates about diversity and inclusion in education. Perhaps the most important diversity is that of life purpose because individuation should not become synonymous with self-interest. Life purpose must be tethered to prosocial effect or the social bonds that are foundational for economic, civic, and societal well-being may become inhibited or lost (see Van de Werfhorst, 2014).

Studies generally agree that social and educational supports are needed for youth to effectively launch a life purpose (Bronk, 2014; Jiang \& Gao, 2018; Malin et al., 2014; Moran, 2019; Moran et al., 2013). Considerable research has pondered the role of teachers and teaching (Moran, 2016; Tirri, 2018). 
Educational models such as problem-based learning (Araujo, Arantes, Danza, Pinheiro, \& Garbin, 2016), crossroads for self-authorship (Pizzolato, 2005) and service-learning (Moran, 2018b) have been promoted. But these perspectives tend to assume stability of worldview. What can educators do when youth face upheavals in worldview?

This paper's analysis offers a few suggestions: conceptualize students as meaning-making contributors not knowledge consumers; embed students in prosocially interdependent situations through which they contribute and gather feedback; design opportunities for students to practice commitment not just exploration; and instill an ecological perspective that appreciates diversity in worldviews and life purposes.

First, in a strongly individuated world, education cannot be "one size fits all" with a standardized, knowledge-focused curriculum. But it also cannot be personalized fully to each student such that students are "served" as knowledge consumers. Both models breed passivity, and neither support prosocial aspirations. Instead, lessons must incorporate-and perhaps emphasizemeaning-making. Students must connect learning experiences both cognitively and emotionally to their personal future, relevant worldview, and societal wellbeing. It is insufficient simply to convey the concept of life purpose (Bundick, \& Tirri, 2014; Moran, 2016). Knowing the definition or dimensions of life purpose provides little guidance for youth to construct a vision of their own contribution to society (Moran, 2016). Although education traditionally has focused on cognitive growth, in a purpose-driven society educators also educate the emotions because purposes are strong conveyors of personal meaning. Without social support for interpreting emotions, young people may get their social signals crossed. For example, studies in Japan noted how difficult it is for students to conceive meaningful personal intentions without conferring with loved ones (Kawai \& Moran, 2017). The ideal is for youths to commit to a specific life aim and develop a habitus (Bourdieu, 1993) - or "feel for" - a purposeful life, realizing the importance of caring about the welfare of others as much as their own (Clydesdale, 2016; Sullivan, 2016).

Second, educators can provide multiple means to show students how they are interdependent with others (Moran, 2018a). For example, providing numerous opportunities to highlight when and how students receive help from others can stimulate humility and gratitude, which can decenter students from feelings of superiority and deservedness (Bronk, 2008). Educators can design opportunities to make visible how - and how much-students' actions impact others (Moran, 2016; Newell, 2012). Connecting academic knowledge to real-world problems shows students what matters and they matter, not only now but into the future (Sullivan, 2016). Service-learning may be particularly effective for these reasons (Moran, 2019). Feedback on youths' prosocial actions must be authentic-from persons or entities who benefited-and not just abstract grades or indirect feedback from the teacher (Moran, 2017b). Then students obtain meaningful indicators that their contribution is integral to a larger social system of interconnected individuals (Moran, 2017b; Sullivan, 2016).

Third, educators can stimulate students' commitment to worthy pursuits (Schwartz et al., 2005) to prevent drifting (Honneth, 2004). Avoid preparing 
students intellectually for the future. Instead, encourage them to think differently about their future - as a necessary compass for their present behavior (Kawai \& Moran, 2017). Educational activities in which students demonstrate actions serving a wider need address why a task - and students' roles in the task-must be continued. Practice through such activities instills a longer-term perspective that focuses not on "checklists" to get tasks done but rather on the enjoyment of contributing to a greater good (Sullivan, 2016).

Finally, diversity itself must be valued as an educational good. Societies are like forests - those with many tree species are more resilient against pestilence than single-species forests (Scott, 1998). The wider the variety of life purposes interacting to support the common good, the stronger the social fabric. Interactions among individuals with diverse life purposes could be an effective way of bringing tacit worldviews to light (Note et al., 2009). From such interactions can emerge new possibilities to interweave individual contributions into a stronger whole (Dent, 1999). To think otherwise can result in what Bourdieu (1993) called "symbolic violence": a person can subconsciously intimidate others and oppress their opportunity to make their own contributions to the world. Education is a key mechanism for leveling the playing field for contributions.

These educational suggestions are modest but potentially powerful. Other scholars have broached similar ideas (Tirri, 2018; Tirri, Moran, \& Mariano, 2016). But these ideas are important to reiterate. Without shifts in educators' beliefs about life purpose development, it is possible that youths may be left to their own wits. Despite the exploration here of the impacts of growing individualistic life purposes among youths worldwide, a more extreme scenario is possible. The growing interest in youth purpose development could be viewed as a failure or abdication of responsibility by societal institutions-including educational institutions-to help youths successfully launch purposeful lives. Instead, youths may have to bear the responsibility on their own to assemble a life purpose from the many and diverse worldviews born of globalization, technology and migration. This situation creates a disturbing gap: who will make sure all these individuals can cooperate and collaborate with each other? That is why the "purpose of education is becoming the education of purpose" (Tirri et al., 2016).

\section{Acknowledgments}

Thank you to the special issue editors and to three anonymous reviewers for their excellent suggestions. A part of this paper was presented as a commentary on cultural and historical roots of youth purpose for a symposium at the 2015 Association for Moral Educational Conference in Santos, Brazil. The student quotes used in the paper are from data collection in the northeast United States, supported in part by The John Templeton Foundation, USA [grant 43284]. The opinions expressed in this article are of the author and do not necessarily reflect the opinions of The John Templeton Foundation. 


\section{References}

Arantes, V., Araujo, U., Pinheiro, V., Marimon, M. M., \& Sastre, G. (2017). Youth purpose through the lens of the Theory of Organizing Models of Thinking. Journal of Moral Education, 46(3), 245-257. doi:10.1080/03057240.2017.1345725

Araujo, U. F., Arantes, V. A., Danza, H. C., Pinheiro, V. P. G., \& Garbin, M. (2016). Principles and methods to guide education for purpose. Journal of Education for Teaching, 42(5), 556-564.

Aristotle. (2000). Nicomachean ethics (R. Crisp, Trans $\mathcal{E}$ Ed.). Cambridge, UK: Cambridge University Press.

Atkinson, W. (2007). Beck, individualization and the death of class: A critique. The British Journal of Sociology, 58(3), 349-366. doi:10.1111/j.1468-4446.2007.00155.x

Balthip, K., McSherry, W., Petchruschatachart, U., Piriyakoontorn, S., \& Liamputtong, P. (2017). Enhancing life purpose among Thai adolescents. Journal of Moral Education, 46(3), 295-307. doi:10.1080/03057240.2017.1347089

Bamberg, M., \& Georgakopoulou, A. (2008). Small stories as a new perspective in narrative and identity analysis. Text $\mathcal{E}$ Talk, 28(3), 377-396. doi:10.1515/TEXT.2008.018

Beck, U., \& Beck-Gernsheim, E. (2002). Individualization: Institutionalized individualism and its social and political consequences. London, UK: Sage.

Bespalov, A., Prudnikova, M., Nyamdorj, B., \& Vlasov, M. (2017). Life aspirations, values and moral foundations in Mongolian youth. Journal of Moral Education, 46(3), 258-271. doi:10.1080/03057240.2017.1347087

Bourdieu, P. (1993). The field of cultural production. New York, NY: Columbia University Press.

Bronk, K. C. (2008). Humility among adolescent purpose exemplars. Journal of Research in Character Education, 6(1), 35-51.

Bronk, K. C. (2014). Purpose in life: A critical component of optimal youth development. New York, NY: Springer.

Bruner, J. (1986). Actual minds, possible worlds. Cambridge, MA: Harvard University Press.

Bruner, J. (1990). Acts of meaning. Cambridge, MA: Harvard University Press.

Bundick, M. J., \& Tirri, K. (2014). Student perceptions of teacher support and competencies for fostering youth purpose and positive youth development: Perspectives from two countries. Applied Developmental Science, 18(3), 148-162. doi:10.1080/10888691.2014.924357

Burnett, B., \& Evans, D. (2016). Designing your life. New York, NY: Knopf.

Clydesdale, T. (2016). The purposeful graduate. Chicago, IL: University of Chicago Press.

Côté, J. (2016). The identity capital model: A handbook of theory, methods, and findings. Sociology Publications. 38. Retrieved from https://ir.lib.uwo.ca/sociologypub/38

Cranney, S. (2013). Do people who believe in God report more meaning in their lives? The existential effects of belief. Journal for the Scientific Study of Religion, 52(3), 638-646. doi:10.1111/jssr.12046

Damon, W. (2008). The path to purpose. New York, NY: Free Press.

Dent, E. B. (1999). Complexity science: A worldview shift. Emergence, 1(4), 5-19. doi:10.1207/s15327000em0104_2

Durkheim, E. (1951). Suicide: A study in sociology. New York, NY: Free Press. [first published in 1897 in French as Le suicide by Ancienne Librairie Germer Bailliere, Paris, France]

Dweck, C. S. (1996). Implicit theories as organizers of goals and behavior. In P. M. 
Gollwitzer \& J. A. Bargh (Eds.), The psychology of action: Linking cognition and motivation to behavior (pp. 69-90). New York, NY: Guilford Press.

Emmons, R. A. (2005). Striving for the sacred: Personal goals, life meaning, and religion. Journal of Social Issues, 61(4), 731-745. doi:10.1111/j.1540-4560.2005.00429.x

Folgueiras, P., \& Palou, B. (2018). An exploratory study of aspirations for change and their effect on purpose among Catalan university students. Journal of Moral Education, 47(2), 186-200. doi:10.1080/03057240.2018.1433643

Hedayati, N., Kuusisto, E., Gholami, K., \& Tirri, K. (2017). Life purposes of Iranian secondary school students. Journal of Moral Education, 46(3), 283-294. doi:10.1080/03057240.2017.1350148

Heng, M. A., Blau, I., Fulmer, G. W., Bi, X., \& Pereira, A. (2017). Adolescents finding purpose: Comparing purpose and life satisfaction in the context of Singaporean and Israeli moral education. Journal of Moral Education, 46(3), 308-322.

Hill, P. L., Burrow, A., L., Brandenberger,J. W., Lapsley, D. K., \& Quaranto, J. C. (2010). Collegiate purpose orientations and well-being in early and middle adulthood. Journal of Applied Developmental Psychology, 31, 173-179. doi:10.1016/j.appdev.2009.12.001

Hill, P. L., Burrow, A. L., \& Sumner, R. (2013). Addressing important questions in the field of adolescent purpose. Child Development Perspectives, 7(4), 232-236. doi:10.1111/cdep.12048

Hofstede, G. (2001). Culture's consequences: Comparing values, behaviors, institutions, and organizations across nations (2nd ed.). Thousand Oaks, CA: Sage.

Honneth, A. (2004). Organized self-realization: Some paradoxes of individualization. European Journal of Social Theory, 7(4), 463-478. doi: 10.1177/1368431004046703

Jiang, F., \& Gao, D. (2018). Are Chinese student teachers' life purposes associated with their perceptions of how much their university supports community service work? Journal of Moral Education, 47(2), 201-216. doi:10.1080/03057240.2018.1430023

Kasser, T., \& Ryan, R. M. (1993). A dark side of the American dream: Correlates of financial success as a central life aspiration. Journal of Personality and Social Psychology, 65(2), 410-422.

Kawai, T., \& Moran, S. (2017). How do future life perspective and present action work in Japanese youth development? Journal of Moral Education, 46(3), 323-336. doi:10.1080/03057240.2017.1350150

Kohli, M. (2007). The institutionalization of the life course: Looking back to look ahead. Research in Human Development, 4(3-4), 253-271. doi: 10.1080/15427600701663122

Koltko-Rivera, M. E. (2004). The psychology of worldviews. Review of General Psychology, 8(1), 3-38. doi:10.1037/1089-2680.8.1.3

Malin, H., Reilly, T. S., Quinn, B., \& Moran, S. (2014). Adolescent purpose development: Exploring empathy, discovering roles, shifting priorities, and creating pathways. Journal of Research on Adolescence, 24(1), 186-199. doi:10.1111/jora.1205

Mason, H. (2017). Inhloso kanye bizo: Exploring South African university students' conceptions and enactment of purpose. Journal of Moral Education, 46(3), 272-282. doi:10.1080/03057240.2017.1345723

McGregor, I. (2006). Offensive defensiveness: Toward an integrative neuroscience of compensatory zeal after mortality salience, personal uncertainty, and other poignant self-threats. Psychological Inquiry, 17(4), 299-308. doi:10.1080/10478400701366977

McGregor, I., Prentice, M. S., \& Nash, K. A. (2009). Personal uncertainty management by reactive approach motivation. Psychological Inquiry, 20(4), 225-229. doi:10.1080/10478400903333460 
McKnight, P. E., \& Kashdan, T. B. (2009). Purpose in life as a system that creates and sustains health and well-being: An integrative, testable theory. Review of General Psychology, 13, 242-251. doi:10.1037/a0017152

Moran, S. (2009). Purpose: Giftedness in intrapersonal intelligence. High Ability Studies, 20(2), 143-159. doi:10.1080/13598130903358501

Moran, S. (2010). Changing the world: Tolerance and creativity aspirations among American youth. High Ability Studies, 21(2), 117-132. doi:10.1080/13598139.2010.525342

Moran, S. (2013). What does "1/2" an intelligence mean? In H. Gardner, E. Winner, \& M. Kornhaber (Eds.), Mind, work, and life: A festschrift for Howard Gardner: Vol. 2 (pp. 168-200). http://www.amazon.com

Moran, S. (2014). Youth's own understandings of purpose: Are there distinct "cultures of purpose"? Applied Developmental Science, 18(3), 1-13. doi:10.1080/10888691.2014.924359

Moran, S. (2016). What do teachers think about youth purpose? The Journal of Education for Teaching, 42(5), 582-601. doi:10.1080/02607476.2016.1226556

Moran, S. (Ed.). (2017a). Special issue: Youth purpose around the world. Journal of Moral Education, 46(3).

Moran, S. (2017b). Youth purpose worldwide: A tapestry of possibilities. Journal of Moral Education, 46(3), 231-244. doi:10.1080/03057240.2017.1355297

Moran, S. (2018a). Purpose-in-action education: Introduction and implications. Journal of Moral Education, 47(2), 145-158. doi:10.1080/03057240.2018.1444001

Moran, S. (Ed.). (2018b). Special issue: Purpose-in-action education. Journal of Moral Education, 47(2).

Moran, S. (2019). Youth life purpose: Evaluating service-learning via development of lifelong 'radar' for community contribution. In P. Aramburuzabala, L. Mcllrath, \& H. Opazo (Eds.), Embedding service-learning in European higher education (pp. 5166). London, UK: Routledge.

Moran, S., Bundick, M. J., Malin, H., \& Reilly, T. S. (2013). How supportive of their specific purposes do youth believe their family and friends are? Journal of Adolescent Research, 28(3), 348-377. doi:10.1177/0743558412457816

Moran, S., \& John-Steiner, V. (2003). Creativity in the making: Vygotsky's contribution to the dialectic of creativity and development. In K. Sawyer, V. John-Steiner, S. Moran, R. J. Sternberg, D. H. Feldman, J. Nakamura, \& M. Csikszentmihalyi (coauthors), Creativity and development (pp. 61-90). New York, NY: Oxford University Press.

Newell, T. (2012). Selling students on the character of liberal arts: A benefit of worldview awareness in education? The Journal of General Education, 61(3), 294-304.

Note, N., Fornet-Betancout, R., Estermann, J. \& Aerts, D. (Eds.). (2009). Worldviews and cultures: Philosophical reflections from an intercultural perspective. Berlin, Germany: Springer.

Opazo, H., Aramburuzabala, P., \& Ramirez, Ch. (2018). Emotions related to Spanish student-teachers' changes in life purposes following service-learning participation. Journal of Moral Education, 47(2), 217-230.

Pew Research Center (2014, September 22). Public sees religion's influence waning [Report]. Retrieved March 14, 2016 from http://www.pewresearch.org/wpcontent/uploads/sites/7/2014/09/Religion-Politics-09-24-PDF-for-web.pdf

Pizzolato, J. E. (2003). Developing self-authorship: Exploring the experiences of high-risk college students. Journal of College Student Development, 44(6), 797-812. doi:10.1353/csd.2003.0074 
Pizzolato, J. E. (2005). Creating crossroads for self-authorship: Investigating the provocative moment. Journal of College Student Development, 46(6), 624-641. doi:10.1353/csd.2005.0064

Pizzolato, J. E., \& Olson, A. B. (2016). Exploring the relationship between the three dimensions of self-authorship. Journal of College Student Development, 57(4), 411427. doi:10.1353/csd.2016.0052

Polanyi, M., \& Prosch, H. (1975). Meaning. Chicago, IL: University of Chicago Press.

Proulx, T. (2009). The feeling of the absurd: Towards an integrative theory of sensemaking. Psychological Inquiry, 20(4), 230-234. doi: 10.1080/10478400903333494

Reason, P. (1998). Toward a participatory worldview. Resurgence, 168, 42-44.

Schwartz, S. J., Côté, J. E., \& Arnett, J. J. (2005). Identity and agency in emerging adulthood: Two developmental routes in the individualization process. Youth $\mathcal{E}$ Society, 37(2), 201-229. doi:10.1177/0044118X05275965

Scott, J. C. (1998). Seeing like a state: How certain schemes to improve the human condition have failed. New Haven, CT: Yale University Press.

Shin, J., Hwang, H., Cho, E., \& McCarthy-Donovan, A. (2013). Current trends in Korean adolescents' social purpose. Journal of Youth Development, 9(2), 16-33.

Smith, C., Christoffersen, K., Davison, H., \& Herzog, P. S. (2011). Lost in transition: The dark side of emerging adulthood. New York, NY: Oxford University Press.

Stillman, T. F., \& Baumeister, R. F. (2009). Uncertainty, belongingness, and four needs for meaning. Psychological Inquiry, 20(4), 249-251. doi: 10.1080/10478400903333544

Sullivan, W. M. (2016). Liberal learning as a quest for purpose. New York, NY: Oxford University Press.

Tirri, K. (2018). The purposeful teacher. In R. Monyai (Ed.), Teacher education in the 21st century. doi:10.5772/intechopen.83437

Tirri, K., \& Quinn, B. (2010). Exploring the role of religion and spirituality in the development of purpose: Case studies of purposeful youth. British Journal of Religious Education, 32(3), 201-214. doi:10.1080/01416200/2010/498607

Tirri, K., \& Ubani, M. (2005). How do gifted girls perceive the meaning of life? Gifted Education International, 19(3), 266-274. doi: 10.1177/026142940501900310

Tirri, K., Moran, S., \& Mariano, J. M. (Eds.). (2016). Special issue: Education for purposeful teaching around the world. The Journal of Education for Teaching, 42(5).

Turkle, S. (2011). Alone together: Why we expect more from technology and less from each other. New York, NY: Basic Books.

US Census Bureau. (2014, December 4). New Census Bureau statistics show how young adults today compare with previous generations in neighborhoods nationwide [Release Number CB14-219]. Retrieved March 16, 2019 from https://www.census.gov

Van de Werfhorst, H. G. (2014). Changing societies and four tasks of schooling: Challenges for strongly differentiated educational systems. International Review of Education, 60, 123-144. doi:10.1007/s11159-014-9410-8

Van den Bos, K. (2009). Making sense of life: The existential self trying to deal with personal uncertainty. Psychological Inquiry, 20(4), 197-217. doi:10.1080/10478400903333411

Van der Kooij, J. C., De Ruyter, D. J., \& Miedema, S. (2015). Can we teach morality without influencing the worldview of students? Journal of Religious Education, 63, 79-93. doi: 10.1007/s40839-016-0022-4

Van Tongeren, D., McIntosh, D. N., Raad, J. M., \& Pae, J. (2013). The existential function of intrinsic religiousness: Moderation of effects of priming religion on intercultural tolerance and afterlife anxiety. Journal for the Scientific Study of 
Religion, 52(3), 508-523. doi:10.1111/jssr.12053

Vidal, C. (2008). Wat is een wereldbeeld? [What is a worldview?]. In H. Ban Belle \& J. Van der Veken (Eds.), Nieuwheid denken: De wetenschappen et het creatieve aspect van de werkelijkheid [Novelty thinking: The science and the creative aspect of reality] (pp. 71-85). Leuven, The Netherlands: Acco. (English version retrieved from http://cogprints.org/6094/)

Waddington, D. I. (2010). Building on treacherous ground: Sense-of-purpose research and demarcating problematic purposes. The Alberta Journal of Educational Research, 56(1), 82-94.

Wicklund, R. A. (1997). Terror management accounts of other theories: Questions for the cultural worldview concept. Psychological Inquiry, 8(1), 54-58. doi:10.1207/s15327965pli0801_12

Yan, Y. (2010). The Chinese path to individuation. The British Journal of Sociology, 61(3), 489-512. doi:10.1111/j.1468-4446.2010.01323.x

\section{Copyrights}

Copyright for this article is retained by the author(s), with first publication rights granted to the journal.

This is an open-access article distributed under the terms and conditions of the Creative Commons Attribution license

(http://creativecommons.org/licenses/by/3.0/). 